\title{
Personal Branding pada Akun Instagram Digital Influencer @boycandra
}

\author{
Nurul Mustaqimmah', Wahyu Firdaus² \\ ${ }^{1,2}$ Universitas Abdurrab \\ Email: nurul.mustaqimmah@univrab.ac.id
}

\begin{abstract}
Instagram is one of the most popular social media today. Instagram is the third highest user with 85 million users (wearesocial, 2021). Personal branding is an impression that is tried to be packaged either intentionally or not about skills, attitudes, behavior and achievements aimed at displaying self-image. One of the users who builds personal branding on Instagram is @ boycandra. This account was chosen because it has an engagement rate of 3.59\%, which means that it is one of the influential influencers on followers. The purpose of this study is to see how an influencer packs his personal branding on the Instagram social media page. This study uses qualitative methods and the theory of eleven elements of personal branding as a research analysis knife. Data collection was obtained from online observations, interviews, and documentation. The results of this study indicate that Boy Candra fulfills eleven personal branding elements, namely upload Boy Candra always prioritizes authenticity, Integrity as character building, always consistently behaves and works, carries the specialization of "kids today", always maintains authority, characteristic of romantic works, relevant from best seller novels to feature films, not only active in one social media, persistent work to produce eighteen books and novels, has a good reputation and began to penetrate the business world.
\end{abstract}

Keywords: Social media, personal branding, Instagram

\begin{abstract}
Abstrak: Instagram merupakan salah satu media sosial terpopuler saat ini. Instagram berada pada urutan ketiga pengguna tertinggi sebanyak 85 Juta pengguna (wearesocial, 2021). Personal branding merupakan suatu kesan yang coba dikemas baik secara sengaja ataupun tidak mengenai keahlian, sikap, perilaku dan prestasi bertujuan untuk menampilkan citra diri. Salah satu pengguna yang membangun personal branding di Instagram adalah @ boycandra. Akun ini dipilih karena memiliki engagement rate sebesar 3,59\% yang artinya sebagai salah satu influencer berpengaruh pada pengikut. Tujuan penelitian ini adalah untuk melihat bagaimana seorang influencer mengemas personal branding pada laman media sosial Instagram. Penelitian ini menggunakan metode kualitatif dan teori sebelas elemen personal branding sebagai pisau analisis penelitian. pengumpulan data diperoleh dari observasi online, wawancara, dan dokumentasi. Hasil penelitian ini menunjukan bahwa Boy Candra memenuhi sebelas elemen personal branding yaitu unggahan Boy Candra selalu mengutamakan keaslian, integritas sebagai pembentuk karakter, selalu konsisten bersikap dan berkarya, mengusung spesialisasi "anak jaman now", selalu menjaga wibawa, ciri khas karya romantis, relevan dari novel best seller ke film layar lebar, tidak hanya aktif di satu media sosial saja, gigih berkarya hingga menghasilkan delapan belas buku dan novel, memiliki reputasi baik dan mulai merambah dunia bisnis.
\end{abstract}

Kata kunci: Media sosial, personal branding, Instagram

\section{Pendahuluan}

Perkembangan teknologi komunikasi saat ini menghasilkan banyak media baru yang populer dikalangan masyarakat satunya media sosial Instagram. Menurut data statistik we are social tahun 2021 Instagram menduduki peringkat tiga pengguna terbanyak yaitu 85 juta pengguna. Media sosial Instagram diciptakan untuk saling berbagi informasi, berbagi pengalaman, berbagi cerita, serta juga untuk mengabadikan sebuah moment. Fitur yang dimiliki 
Instagram memungkinkan seseorang untuk membangun citra diri dalam laman akun sosial medianya. (wearesocial, 2021).

Tidak hanya digunakan untuk kepentingan pribadi, Instagram juga sering digunakan oleh beberapa kalangan sebagai media promosi, baik promosi produk, tempat dan bahkan dimanfaatkan sebagai media untuk menciptakan identitas (Personal Branding). Wright (2010) menjelaskan Personal Branding melibatkan pengelolaan reputasi, gaya, penampilan, sikap, dan keterampilan yang sejalan dan teratur dengan sebuah regu pemasar yang memasarkan suatu brand (Fitriani, 2019).

Rampersad (2018) menyatakan sebelas karakter personal branding yaitu pertama Authenticity (keaslian) adalah sebuah istilah tehnis dalam filosofi eksistensialis, dan juga digunakan dalam filosofi seni dan psikologi. Authenticity menggambarkan tingkatan kekuatan pribadi, spirit, dan karakter seseorang dalam menghadapi pengaruh tekanan lingkungan eksternal. Dalam psikologi, authenticity menunjukkan kehendak kuat untuk hidup menurut kata hati (inner being) ketimbang tekanan dan tuntutan masyarakat. Secara sederhana, authenticity bicara tentang bagaimana menjadi diri sendiri yakni berbuat, berperilaku dan berpenampilan sesuai prinsip yang diyakini atau menurut kata hati, bukan karena tekanan lingkungan, bukan didikte oleh standar nilai yang ditentukan lingkungan (sosial, budaya dan politik), hal Ini dibangun atas kepribadian sejati dalam diri dan mencerminkan karakter, nilai nilai, dan visi yang dimiliki pribadi tanpa ada pengaruhnya dari orang lain, sehingga keaslian yang terbentuk murni hasilnya. Kedua Integrity (integritas) adalah suatu keadaan atau sikap seseorang yang berkualitas, jujur, berwibawa dan selalu bertindak benar. Kemudian secara konsisten memepertahankan setiap prinsip yang di pegangnya menjadi suatu gabungan yang menyatu secara utuh didalam dirinya, meski dalam kondisi yang bertentangan, sikap ini akan menunjukan kualitas diri sebagai yang dilihat memiliki integritas tinggi akan setiap karya yang ia miliki. Ketiga Consistency (konsisten) yakni kemampuan untuk terus menerus berusaha sampai suatu pencapaian berhasil diraih, tidak ada satu hal didunia ini yang bisa menggantikan konsistensi. Bakat atau talenta, skill, keberuntungan, kepintaran, semua itu tidak ada artinya tanpa konsistensi, bahkan dalam kasus tertentu konsistensi bisa mengalahkan kualitas, kita sudah sering melihat daily vlogger yang isinya cenderung biasa mampu lebih sukses dibandingkan konten kreator lain yang lebih berkualitas karena mereka konsisten mengupload videonya setiap hari. Faktanya akan selalu ada orang yang lebih berbakat dari Anda, lebih kaya, lebih pintar, lebih baik, lebih rupawan, lebih kreatif, dan seterusnya, namun ada satu hal yang bisa Anda lakukan untuk menjadi lebih baik dari mereka yaitu anda bisa lebih kuat bekerja atau berusaha. Dalam personal branding, konsisten juga sangat dibutuhkan melihat membangun identitas membutuhkan waktu yang tidak sebentar (Rampersad, 2008).

Kemudian yang ke-empat, Specialization (spesialisasi) fokus terhadap satu bidang bakat atau keterampilan. Spesialisasi berarti fokus pada aspek spesifik dari sesuatu yang lebih besar. Ini dapat dikaitkan dengan produk, tugas, pekerjaan atau keahlian. Dengan fokus, individu, perusahaan atau negara menjadi semakin ahli. Mereka mendapatkan manfaat besar dari kurva pembelajaran dan pengalaman, sehingga membuat mereka lebih efisien. Dengan kata lain, semua orang bisa melakukan hal yang sama tetapi hasilnya berbeda dengan orang yang memang menjadi spesialisasi dalam bidang tertentu, kualitas yang dihasilkan tentu saja sangat berbeda dengan orang yang tidak memiliki spesialisasi, karna itu spesialisasi dibutuhkan dalam 
membangun identitas diri. Kelima, Authority (wibawa) Sikap wibawa seseroang dipengaruhi oleh beberapa faktor yaitu sikap atau perilaku, pendidikan, pengetahuan, atau wawasan, penampilan, kecerdasan, cerdas membawa diri, diakui dalam bidang tertentu, berpengalaman, dan sebagai pemimpin yang efektif. Keenam, Distinctiveness (kekhasan) Kekhasan adalah sebuah keistimewaan yang kita miliki, entah itu diperoleh sejak lahir ataupun diperoleh dari pengalaman, dalam proses pembentukan identitas, ini sangat dibutuhkan, berhubung sikap ini selain mampu membuat berbeda dengan orang lain, sikap ini juga mampu menjadi suatu nilai plus untuk khalayak, karena pasti tidak dimiliki oleh orang lain, meski dalam bidang yang sama atau bentuk yang sama. Ketujuh, Relevant (relevan) Menurut (Ainon Mohm, 2005), relevan adalah mempunyai kaitan dan hubungan erat dengan pokok masalah yang sedang dihadapi. Revalan merupakan hal-hal yang sejenis yang saling berkaitan dengan subjek dalam konteks yang tepat atau terhubung dan terkait dengan situasi saat ini. Kedelapan Visibility (visibilitas), Visibilitas dalam Authentic Personal branding diartikan (Rampersad, 2008) sebagai penyampaian pesan yang berkali-kali dan terus menerus. sedikit berbeda dengan konsistensi, ini berarti pesan yang disampaikan tidak hanya dalam bentuk unggahan atau karya, tetapi juga dalam bentuk cara menyampaikan pesan kepada pengikutnya melalui media lain. Kesembilan, Persistence (kegigihan) Kegigihan adalah semangat pantang menyerah yang harus dimiliki untuk mencapai kesuksesan. Setiap manusia harus dapat membiasakan diri melihat setiap masalah yang muncul sebagai suatu hal yang wajar dan harus dihadapi, bukan menghindar atau melarikan diri dari masalah (Rampersad, 2008).

Berdasarkan penjelasan Rampersad tersebut, bisa dilihat selain reputasi, gaya, penampilan dan sikap, keterampilan yang sejalan dan teratur juga akan membangun sebuah Personal Branding yang bagus. Personal branding yang baik dapat terbentuk dengan memiliki kesembilan elemen penting yang dikemukakan oleh Rampersad diantaranya keaslian (Authenticity), integritas (Integrity), konsisten (Consistency), spesialisasi (Specialization), wibawa (Authority), kekhasan (Distictiveness), relevansi (Relevant), visibilitas (Visibility), kegigihan (Persistence), kebaikan (Goodwill), kinerja (Performance).

Instagram menjadi salah satu media yang menarik untuk dijadikan sebuah media Personal Branding dikarenakan tingginya pengguna Instagram di Indonesia. Membangun Personal Branding bisa dilihat dari unggahan yang disajikan oleh pemilik akun yang bersangkutan. Jika unggahannya terlihat konsisten bisa disebut sedang membangun sebuah karakter diri melalui media sosial. Dari halaman website menjelaskan bahwa Instagram tersusun dari dua kata yaitu "insta" dan "gram". Arti kata pertama diambil dari kata "instant" yaitu serba cepat atau mudah, sedangkan kata "gram" diambil dari "telegram" yang maknanya dikaitkan dengan media pengiriman informasi yang sangat cepat. Selain itu, Instagram juga dapat diartikan sebagai sebuah aplikasi jejaring sosial untuk berbagi foto yang memungkinkan pengguna mengambil foto, menerapkan filter digital, dan membagikan ke berbagai layanan jejaring sosial, termasuk milik Instagram sendiri (Surijah, 2017).

Fitur-fitur dalam Instagram yang digunakan tergantung kebutuhan pemilik akun sendiri, dari banyak fitur yang disediakan penulis mengambil beberapa fitur yaitu Follower, upload foto, judul foto, tanda like, explore. Fitur Instagram yang banyak digunakan berdasarkan hasil penelitian terdahulu Soraya (2017) adalah sebagai berikut, pertama, Followers (Pengikut) Sistem sosial di dalam Instagram adalah dengan menjadi pengikut akun pengguna lainnya, atau 
memiliki pengikut Instagram. Dengan demikian komunikasi antara sesama pengguna Instagram sendiri dapat terjalin dengan memberikan tanda suka dan juga mengomentari fotofoto yang telah diunggah oleh pengguna lainnya. Pengikut juga menjadi salah satu unsur yang penting, dimana jumlah tanda suka dari para pengikut sangat mempengaruhi apakah foto tersebut dapat menjadi sebuah foto yang populer atau tidak. Untuk menemukan teman-teman yang ada di dalam Instagram. Kemudian, Upload Foto (Mengunggah Foto), Kegunaan utama dari Instagram adalah sebagai tempat untuk mengunggah dan berbagi foto-foto kepada pengguna lainnya. Foto yang hendak ingin diunggah dapat diperoleh melalui kamera iDevice ataupun foto-foto yang ada di album foto di iDevice tersebut. Kemudian selanjutnya adalah Judul foto. Setelah foto tersebut disunting, maka foto akan dibawa ke halaman selanjutnya, dimana foto tersebut akan diunggah ke dalam Instagram sendiri ataupun ke jejaring sosial lainnya. Dimana di dalamnya tidak hanya ada pilihan untuk mengunggah pada jejaring sosial atau tidak, tetapi juga untuk memasukkan judul foto, dan menambahkan lokasi foto tersebut (Soraya, 2017).

Tanda suka (like), Instagram juga memiliki sebuah fitur tanda suka yang fungsinya memiliki kesamaan dengan yang disediakan Facebook, yaitu sebagai penanda bahwa pengguna yang lain menyukai foto yang telah diunggah. Berdasarkan dengan durasi waktu dan jumlah suka pada sebuah foto di dalam Instagram, hal itulah yang menjadi faktor khusus yang mempengaruhi foto tersebut terkenal atau tidak. Lain lagi dengan fitur Explore, Bila sebuah foto masuk ke dalam halaman populer, yang merupakan tempat kumpulan dari foto-foto populer dari seluruh dunia pada saat itu. Secara tidak langsung foto tersebut akan menjadi suatu hal yang dikenal oleh masyarakat mancanegara, sehingga jumlah pengikut juga dapat bertambah lebih banyak (Soraya, 2017).

Fenomena Instagram dalam membangun karakter diri telah banyak dilakukan oleh pengguna Instagram tersebut. Para selebrity instagram saling membangun identitas mereka melalui unggahan instagram agar dapat dijadikan endorser untuk suatu produk atau jasa. Berdasarkan penjabaran fenomena Instagram di atas, penulis melihat adanya pemanfaatan Instagram untuk mengembangkan berbagai macam hal, baik itu untuk membangun citra dan karakter pribadi, maupun untuk kelompok atau golongan.

Semakin banyaknya pemanfaatan Instagram dalam pembentukan identitas diri membuat para seniman, penjual online maupun perusahaan saling berusaha dalam membangun identitas positif mereka dengan memanfaatkan perkembangan teknologi komunikasi di era digital. Ditambah interface aplikasi pada Instagram pun terbilang mudah digunakan oleh semua kalangan, serta pengguna Instagram juga tidak terbatas rentang usianya, sehingga semua orang bisa menggunakannya.

Pada penelitian ini penulis menjadikan akun Instagram @boycandra sebagai objek penelitian. Penulis melihat pemilik akun @ boycandra memiliki Personal Branding yang kuat, terbukti banyaknya like pada setiap unggahannya. Sebagai seorang penulis novel yang menggunakan Instagram, ia memiliki enggagement yang kuat dengan followers Instagramnya. Ia memiliki followers sebanyak 1,9 juta dan telah mengunggah 3.882 materi pada akun Instagram miliknya. tidak hanya untuk mempromosikan novel-novelnya, ia juga mengunggah potongan-potongan kata untuk menunjukan bahwa ia adalah seorang penulis profesional. 
Berdasarkan perhitungan enggament rate Instagram pada akun @boycandra, ia meraih sebanyak 3,54\% berdasarkan 12 postingan terakhir, dengan rumus 12 postingan terakhir (like + komentar / jumlah followers). terhitung sejak tanggal 27 mei 2020, ini menjadikan salah satu alasan yang kuat penulis untuk menjadikan @ boycandra sebagai digital influencer berpengaruh karena memiliki kategori rate yang tinggi. (mee, 2018)

Tabel 1 : Klasifikasi Engagement Rate

\begin{tabular}{cc}
\hline Engagement Rate & Klasifikasi \\
\hline$<1 \%$ & Rendah \\
\hline $1 \%-3,5 \%$ & Rata-Rata / Baik \\
\hline $3,5 \%-6 \%$ & Tinggi \\
\hline$>6 \%$ & Sangat Tinggi \\
\hline
\end{tabular}

Sumber : Mee, 2018

Digital influencer adalah seseorang yang memiliki kemampuan untuk mempengaruhi orang lain menggunakan platform digital miliknya. Pengaruh yang diberikan dapat berupa perubahan opini, sikap, dan perilaku. Hal ini disebabkan oleh pengikut digital influencer yang jumlahnya banyak. Akan tetapi pengikut yang banyak saja tidak dapat menjadi tolak ukur kekuatan "influence" yang diberikan. Seorang digital influence juga harus memiliki aspek reach, resonance dan relevance atau dalam bahasa sederhananya "engangement" kepada pengikutnya. Beberapa tahun belakangan ini, media sosial dan digital influencer telah mengambil peranan penting dalam bidang promosi. Khususnya instagram yang diawal tahun 2019 telah mencapai angka 56jt pengguna aktif. Hal ini memungkinkan instagram membentuk komunitas besar yang terklasifikasi dan memudahkan ketepatan sasaran komunikator (Solis, 2012).

Digital Influencer dalam kesehariaanya selalu konsisten membangun hubungan baik dan membentuk citra positif yang sesuai dengan minat dari pengikut. Kemampuan membangun sebuah komunitas yang besar memungkinkan digital influencer dapat dengan mudah merubah perilaku followers. Seperti penelitian terdahulu (Evelina dan Handayani, 2018) yang mendeskripsikan peranan digital influencer dalam promosi produk kosmetik dengan hasil penelitian promosi melalui platform digital lebih unggul dibanding promosi konvensional. Penelitian terdahulu lainnya yaitu (Mustaqimmah, 2020) menunjukkan bahwa seorang dokter yang menjadi digital influencer mampu melakukan proses komunikasi kesehatan dengan menggunakan platform instgaram dengan mengelaborasi konsep 4C yaitu Communication, Connection, Context dan Collaboration.

Kekuatan platform digital dapat dilihat dari hasil penelitian terdahulu dimana seorang digital influencer mampu membentuk perilaku menyimpang remaja sehingga menyebabkan kepanikan moral terjadi di kota Pekanbaru. Akan tetapi tidak sedikit juga digital influencer yang mampu menggunakan platform ini ke arah positif. Seperti yang dilakukan oleh seorang digital influencer Boy Candra, menampilkan karya tulisannya di laman media sosial Instagram dan memantain personal branding melalui instagramnya (Mustaqimmah, 2017).

Berdasarkan latar belakang yang sudah dipaparkan, tujuan penulisan ini adalah penulis ingin menguak bagaimana seorang digital influencer @boycandra mengemas personal 
brandingnya di media sosial Instagram? Artikel ini bertujuan untuk mengulas bagaimana seorang digital influencer mengemas personal brandingnya di media sosial.

\section{Metode}

Metode penelitian yang akan digunakan adalah dengan pendekatan kualitatif dan metode studi kasus. Pendekatan kualitatif ini dengan cara observasi online akun instagram digital influencer @ boycandra. Tahapan pertama, peneliti beserta anggota dan pembantu peneliti melakukan FGD membahas persiapan penelitian. Setelah diskusi, dirumuskanlah langkah-langkah penelitian yang tergambar pada diagram alir penelitian. Tahapan kedua peneliti dan anggota mulai mengamati atau pra observasi online akun instagram yang menjadi subjek penelitian dan mewawancarai Boy Candra ini sendiri. Hal ini juga didukung dengan studi pustaka yang peneliti lakukan. Setelah tahapan tesebut dilakukan dan dapatlah fokus penelitan yang menjadi identifikasi masalah yang akan diteliti yaitu ingin melihat bagaimana salah satu digital influencer mengemas personal branding di media sosial Instagram.

Fokus penelitan yang menjadi identifikasi masalah yang diteliti yaitu pertama ingin mendeskripsikan Digital Influencer, kedua ingin melihat digital influencer Boy Candra ini mengemas personal branding pada laman akun Instagramnya. Tahapan berikutnya peneliti mulai melakukan observasi online. Peneliti mengumpulkan konten-konten pada akun subjek dan mengamati unggahan instagram per hari serta melihat enggagement subjek dan followers.

Setelah semua data diperoleh peneliti mulai melakukan persiapan pengolahan data. Seluruh data didiskusikan pada pertemuan FGD dengan anggota peneliti lain. Setelah diadakan pertemuan FGD, data yang telah terkumpul diolah terlebih dahulu. tujuannya adalah untuk menyederhanakan seluruh data yang terkumpul. Kemudian menyajikannya dalam susunan yang baik dan rapi kemudian akan dilakukan tahapan persiapan analisis data. Analisis data dimulai dari analisis berbagai data yang berhasil dikumpulkan melalui observasi online dan literatur media. Selanjutnya data tersebut diklasifikasikan menjadi kategori tertentu. Analisis teknik komparatif konstan melalui tahapan sebagai berikut: Menempatkan data ke dalam beberapa kategori; membandingkan tiap kategori agar tidak tumpang tindih; mencari hubungan antarkategori, menyederhanakan dan mengaitkan dengan teori yang digunakan. Setelah analisis dilakukan perumusan hasil, pembahasan dan penyusunan laporan akhir.

\section{Hasil dan Pembahasan \\ Profil Boy Candra}

Boy Candra adalah seorang laki laki kelahiran 21 november 1989 di Sumatera Barat, pernah mengecap pendidikan di Universitas Negeri Padang jurusan Administrasi Pendidikan. Ia juga aktif di organisasi Komunikasi dan Radio kampus (UKKPK UNP). Salas seorang yang memiliki hobi menulis ini ternyata sudah suka menulis sejak ia masih SD, dan pada tahun 2011 ia mulai aktif menulis dengan ciri khas tulisan mengikuti anak remaja zama sekarang. Aktif menulis sejak 2011, ia berhasil di tahun 2013 menerbitkan sebuah buku dengan nuasa romance dengan judul Origami Hati, dan terus berlanjut tahun 2014 menerbitkan buku dengan judul Setelah Hujan Reda, di tahun 2015 menerbitkan dua buku yaitu Cinta Yang Panjang dan Senja, Hujan, dan Cerita yang Telah Usai. Karir nya sebagai penulis dengan memakan pasar anak muda zaman sekarang membawa ia menjadi penulis ternama saat ini, buku nya laris di pasaran, 
dan sekarang ia sedang menggarap sebuah film dengan judul Malik dan Elsa yang akan tayang pada tahun 2020.

\section{Boy Candra di Media Sosial}

Beliau tidak hanya aktif dalam organisasi kampus, tapi aktif di media sosial nya, dua dari platform sosial media yang ada di Indonesia, Boy Candra memiliki 2 akun yang memiliki banyak pengikutnya, dua akun tersebut ialah Instagram dan Twitter. Akun Instagram Boy Candra sendiri memiliki pengikut sampai tanggal 2 Juli 2020 sebanyak 1,9 juta pengikut, dengan total unggahan 3.882 unggahan. Akun Instagram nya juga sudah terverifikasi oleh pihak Instagram sendiri, bisa dilihat disamping username terdapat simbol atau tanda ceklis biru.

Instagram dan Twitter merupakan dua aplikasi yang aktif digunakan oleh Boy Candra. Twitter Boy Candra memiliki total pengikut sebanyak 2,8 juta pengikut atau yang biasa disebut dengan Followers. Sebagai seorang penulis, cuitan nya di Twitter juga memiliki pesan tentang remaja zaman sekarang. Beberapa cuitannya di Twitter juga menghasilkan enggament yang cukup besar. Salah satu cuitan nya ada menghasilkan 1.141 komentar, 415 retweet dan 8.733 like dalam kurun waktu beberapa jam saja.

\section{Personal Branding Boy Candra di Media Sosial}

Setiap unggahan yang di unggah dalam akun instagram Boy Candra selalu megutamakan keaslian nya, sebagai seorang penulis ia selalu mengunggah potongan-potongan tulisan untuk membangun personal branding nya. Beberapa unggahan Boy Candra berdasarkan potongan tulisan yang ada didalam buku nya, dan yang memperkuat keaslian unggahan boy chandra ialah selalu memberikan watermark disetiap unggahan nya, yang menjelaskan unggahan itu adalah asli milik nya. Dalam hal ini tidak ada kegiatan plagiat atau tindakan yang meniru, menjilpak, mencotoh tulisan penulis atau orang lain,

Berdasarkan teori Rampersad diatas unggahan tersebut menunjukan keaslian nya sebagai seorang penulis yang menjaga personal branding nya terhadap khalayak ataupun followers nya. Berikut Unggahan Boy Candra tanggal 1 juli 2020 yang mengandung unsur Authencity (keaslian) :

Gambar 1

Unggahan Boy Candra tanggal 1 juli 2020

\footnotetext{
Aku pernah belajar merelakanmu berkalikali. Melepasmu pergi dengan cinta yang lain. Membiarkan kesempatan memilikimu hilang untukku. Sebab kamu berhak bahagia; meski sesungguhnya aku tidak bahagia dengan keputusan itu. Ketidakberanianku mengikatmu memberi ruang bagi orang asing mendekatimu. boy candra
}

Sumber : Akun Instagram @ boycandra 
Menjadi seorang penulis seperti Boy Candra tidak hanya sekedar mengandalkan tulisan, ataupun buku yang ia terbitkan, tetapi ia juga memiliki integritas yang tinggi terhadap tulisan nya. Sebagai penulis, Boy Candra menunjukan integritas melalui tulisan yang ia tulis. Integritas yang Boy Candra tampilkan ialah membangun prinsip prinsip untuk menunjukan kualitas dirinya sebagai seorang penulis. Pada akun instagram milik nya, ia selalu mengunggah tulisan berdasarkan apa yang ia tulis, ini menggambarkan Boy Candra memiliki integritas terhadap tulisan nya didalam akun instagram milik nya.

Berdasarkan grand theory pada penelitian ini, integritas adalah suatu keadaan atau sikap seseorang yang berkualitas, jujur, berwibawa dan selalu bertindak benar. Kemudian secara konsisten mempertahankan setiap prinsip yang di pegangnya menjadi suatu gabungan yang menyatu secara utuh didalam dirinya, meski dalam kondisi yang bertentangan, sikap ini akan menunjukan kualitas diri sebagai yang dilihat memiliki integritas tinggi akan setiap karya yang ia miliki.

Dibutuhkan konsistensi yang juga kuat agar personal branding tetap terjaga dengan baik. Boy Candra sendiri dalam hal membangun personal branding nya disipilin terhadap konsistensi di sosial media instagaram milik nya. (Rampersad, 2008) Konsistensi tidak hanya melihat dalam kesamaan waktu dalam mengunggah, tetapi juga bisa dilihat dari konsisten dalam berprilaku (Butar \& Ali, 2018). Ini bertujuan agar para followers yakin terhadap brand yang sedang dibangun. Boy Candra merupakan seorang penulis profesional, buku-buku yang ia terbitkan selalu mengangkat kisah romansa anak muda, ini juga menunjukan konsistensi nya sebagai penulis. Begitu juga dalam akun Instagram nya, ia selalu konsisten mengunggah tulisan dengan gaya romance, sehingga semua orang tau ini benar adalah tulisan nya. Dengan gaya tulisan romance nya menunjukan bahwa Boy Candra konsisten dengan gaya penulisan seperti itu.

Gambar 2

Unggahan Boy Candra tanggal 2 juli 2020

Kadang beberapa omongan orang itu bisa jadi sumber penyakit. Semakin kamu pikirkan, malah bikin kamu tambah sakit Maka abaikan saja. Anggap saja sesuatu yang telah dibuang pada tempatnya. boy candra

Sumber : Akun Instagram @boycandra

Banyak hal yang dilakukan oleh seorang penulis untuk menarik pembaca agar tertarik untuk membaca tulisan yang ia tulis, salah satu nya yaitu dengan menentukan genre dalam tulisan nya. Salah satu nya Boy Candra, ia merupakan penulis yang memiliki genre yang disukai oleh kalangan remaja, unggahan dalam instagram milik nya menunjukan ia sebagai spesialis 
anak muda yang tidak lepas dari romantika percintaan, patah hati dan persahabatan. Dengan memiliki spesialisasi sebagai penulis dengan genre romantis membuat unggahan nya di Instagram banyak disukai oleh orang banyak, karena kebanyakan tulisan yang ia tulis dan unggahan nya dalam akun instagram miliki nya erat kaitan dengan yang dialami oleh anak-anak muda zaman sekarang.

Menurut penulis, Boy Candra telah memenuhi unsur spesialisasi dalam sebelas teori personal branding oleh Rampersad, karena @ boycandra memiliki genre penulisan yang spesifik dan fokus kepada satu genre yang membuat ia mudah dikenal oleh khalayak dalam membangun personal brandingnya.

Dari sebelas indikator personal branding oleh Rampersad (2008), wibawa (Authority) menjadi salah satu faktor yang penting dalam membangun personal branding. Sikap wibawa seseroang dipengaruhi oleh beberapa faktor yaitu sikap atau perilaku, pendidikan, pengetahuan, atau wawasan, penampilan, kecerdasan, cerdas membawa diri, diakui dalam bidang tertentu, berpengalaman, dan sebagai pemimpin yang efektif.

Boy Candra di sosial media milik nya, tidak selalu menuai pujian dari unggahan yang ia unggah di Instagram, banyak juga komentar negatif di unggahan tersebut. Boy Candra tetap tenang menanggapi komentar negatif agar branding sebagai seorang penulis romantis yang telah dibangun tetap terjaga dengan baik.

Menurut peneliti, pengalaman Boy Candra yang tidak sebentar dalam dunia sosial media membuat nya semakin dewasa dalam menanggapi hal miring yang menerpanya di media sosial. Ini telah menunjukan unsur wibawa yang terdapat dalam teori personal branding oleh (Rampersad, 2008).

\section{Kekhasan Boy Candra Sebagai Penulis}

Salah satu poin penting yang juga termasuk dalam grand teori pada penelitian ini ialah kekhasan. Kekhasan merupakan sebuah keistimewaan yang kita miliki entah itu diperoleh sejak lahir ataupun diperoleh dari pengalaman. Dalam proses pembentukan identitas, ini sangat dibutuhkan, berhubung sikap ini selain mampu membuat berbeda dengan orang lain, sikap ini juga mampu menjadi suatu nilai plus untuk khalayak, karena pasti tidak dimiliki oleh orang lain, meski dalam bidang yang sama atau bentuk yang sama.

Menurut pengamatan peneliti, berdasarkan grand teori pada penelitian ini, seorang boy candra memiliki ciri khas pada setiap unggahannya yang mampu menarik ataupun menghasilkan enggagement dengan followers nya, ia selalu menggunggah tulisan yang selalu relate dengan apa yang dirasakan anak muda sekarang salah satunya karya-karya bernuansa romantis. Sehingga, setiap tulisan yang ia hasilkan menghasilkan kekhasan tersendiri yaitu romantic.

\section{Relevan dari Novel Best Seller ke Film Layar Lebar}

Berkaitan dengan relevan, kini Boy Candra tidak hanya bergelut dibidang menulis saja, karirnya sebagai menulis lambat laun membawa nya terjun ke dunia film. Ini dapat dibuktikan dengan salah satu film yang berjudul "Seperti Hujan yang Jatuh ke Bumi" yang diproduksi oleh screenplay film. Film ini di adopsi dari salah satu novel best seller yang ia terbitkan, tidak tanggung tanggung, film ini dibintangi oleh aktor papan atas yang ada di indonesia. 
Gambar 3

Unggahan Boy Candra tanggal 27 April 2020

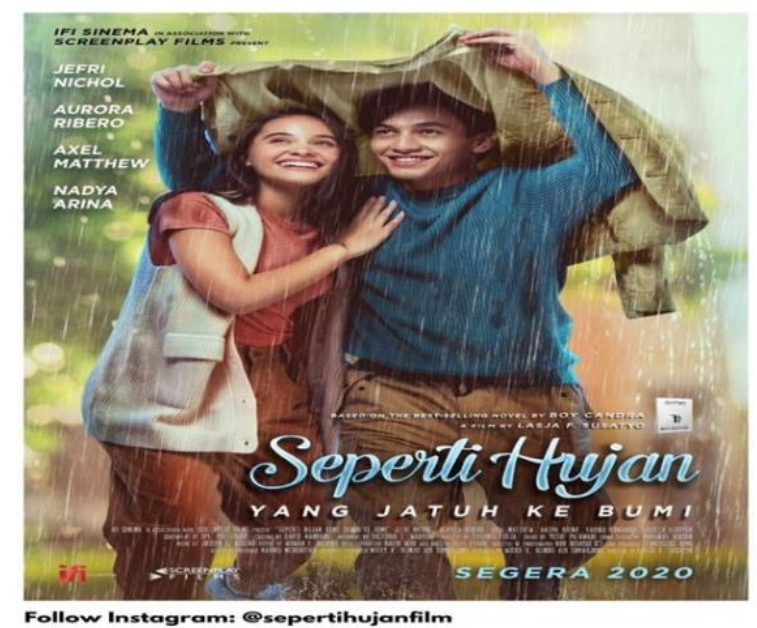

Sumber : Akun Instagram @ Boycandra

Berdasarkan grand teori, menurut penulis Boy Candra telah memenuhi unsur relevan, kemampuan nya menulis tidak hanya dinikmati oleh khalayak lewat membaca, namun sekarang bisa melihat adaptasi tulisan nya melalui layar lebar.

\section{Kegigihan Boy Candra Menerbitkan Delapan Belas Buku dan Novel}

Keberhasilan Boy Candra saat ini tidak lain hasil dari kegigihan dan kerja keras nya, ia menekuni menulis bahkan sejak di bangku perkuliahan. Hasil yang ia dapat saat ini adalah suatu buah dari kegigihan nya sebagai seorang penulis. Karir nya sebagai penulis menunjukan bahwa ia gigih dan tekun atas apa yang kerjakan, terbukti ia telah menerbitkan 18 buku dan novel.

\section{Pandangan Pengikut Boy Candra Terhadap Brandingnya}

Berdasarkan grand teori pada penelitian ini, kebaikan (goodwill) di perlukan dalam mempertahankan branding yang elah dibangun sebelumnya, goodwill berarti memberikan manfaat kepada orang banyak atau para pengikut nya. Boy candra telah memberi sebuah pandangan positif tentang penulis, bagaimana menulis merupakan sebuah karya yang harus di apresiasi. Ia mampu menciptakan citra penulis menjadi kembali banyak digemari ditengah kurang nya minat baca pada era saat ini.

\section{Boy Candra dalam Bisnis Clothing}

Tidak hanya fokus menjadi penulis, seorang boy candra juga mengembangkan branding nya ke bentuk lain. Ia mencoba memanfaatkan personal branding yang telah ia bangun dari dulu dengan membuat sebuah usaha clothing yang dinamakan bakaus.co. Sesuai dengan biografi pada Instagram @bakaus.co, Boy Candra berusaha untuk mengabadikan kata kata kedalam berbagai rupa, salah satu nya kedalam bentuk baju kaos. Pada akun Instagram Boy Candra sendiri ia menyematkan nama bakaus.co untuk menginformasikan usaha baru yang ia kembangkan. Menurut penulis, berdasarkan grand teori pada penelitian ini, boy candra telah memenuhi unsur kinerja, yaitu ia mengembangkan kualitas hidup nya dengan memanfaatkan branding yang ia bangun kedalam bentuk bisnis clothing. 


\section{Gambar 5}

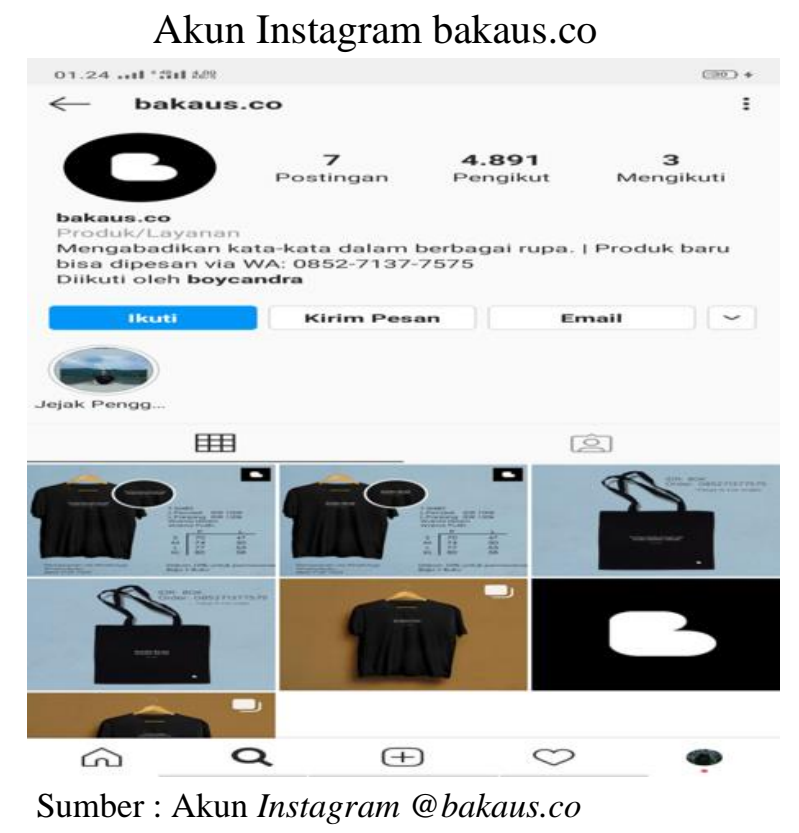

\section{Simpulan}

Berdasarkan pembahasan diatas dapat disimpulkan bahwa seorang digital influencer mengimplementasikan sebelas konsep dasar personal branding dalam kesehariannya di media sosial Instagram. Salah satu digital influencer tersebut adalah Boy Candra yang memang aktif berinteraksi di dunia maya. Adapun sebelas elemen penting teori personal branding menurut Rampersad (2008) antara lain yaitu Boy Candra selalu mengutamakan keaslian dalam setiap postingannya (Authenticy) dengan menyematkan watermark. Boy Candra juga memiliki integritas (Integrity) yang tinggi dengan menanamkan nilai-nilai kejujuran atas apa yang ia tulis dan unggah. Ketiga, Boy Candra selalu konsisten dalam menulis tidak sekedar konsisten (consistency) terhadap waktu mengunggah postingan tetapi juga konsisten dalam gaya penulisan yang secara spesifik merujuk pada gaya penulisan anak muda. Dalam menanggapi kritikan dari followers Boy Candra selalu mengedepankan sikap yang tenang sehingga wibawa (Authority) sebagai penulis tetap terjaga. Selain itu tentu saja dalam membentuk personal branding seseorang harus memiliki kekhasan tersendiri (distinctiveness) dimana Boy Candra selalu mengusung kekhasan kisah romansa anak muda dan juga buku-buku dan karya yang ia hasilkan selalu relevan (relevance) dengan apa yang ia tampilkan di media sosial Instagram. Salah satu novel terbaiknya tentang kisah romansa anak muda juga berhasil diangkat menjadi film layar lebar Indonesia. Boy Candra juga tidak hanya pupuler di akun Instagram saja, melainkan juga aktif dan dikenal di akun twitter yang mengokohkan bawah beliau juga sosok yang memiliki Visibilitas (visibility) yang tinggi. Karir yang dibangun dari 2013 hingga saat ini membuahkan hasil berkat kegigihannya dalam menghasilkan karya baru. Terkait kebaikan (goodwill) Boy Candra juga membuat sebuah forum penggalangan dana untuk membantu orang-orang yang membutuhkan. Tidak hanya menulis, Boy Candra juga mencoba peruntungannya dengan memanfaatkan kinerja (performance) atau potensi yang dimiliki di dunia bisnis yaitu clothingline yang bernama bakaus.co. berdasarkan pemaparan diatas, penulis telah menjabarkan bagaimana seorang digital influencer membentuk personal brandingnya pada akun media sosial Instagram. Diharapkan penelitian ini dapat menjadi bahan referensi bagi 
pembaca untuk mampu mengemas personal branding yang baik pada media sosial Instagram ataupun media lainnya.

\section{Referensi}

Adib, H. (2018). Boy Candra, Penulis Muda Sumatera Barat Yang Sedang Naik Daun. Diakses pada 16 Agustus 2020, dari http://sumaterakita.com/baca/148/boy-candra-penulismuda-sumatra-barat-yang-sedang-naik-daun

Afrilia, M. (2018). Personal Branding remaja digital. Jurnal komunikasi 11(1). 20-30

Angelica, V. \& Setyanto, Y. (2019). Media Sosial Dalam Pembentukan Personal Branding (studi pada Instagram Alberta Claudia). Jurnal komunikasi. 3(1). 274-282

Bungin, B. (2015). Penelitian Kualitatif. Jakarta: Prenada Media Group

Butar, R., Ali, S. (2018). Strategi Personal Branding Selebgram Non Selebriti. Jurnal ilmiah hubungan masyarakat. 2(2). 85-101

Cara Menghitung Enggament Rate Instagram. (2019). Diakses pada 16 Agustus 2020, dari https://www.fillyawie.com/2019/03/cara-menghitung-engagement-rate.html

Evelia, Handayani, 2018. Penggunaan Digital Influencer dalam promosi Produk (Studi Kasus pada Akun Instagram @bylizzieparra). Jurnal Warta ISKI 01(01): pp. 71-82

Faradiza, N. (2018). Strategi Komunikasi Dinas Pariwisata dan Kebudayaan Kabupaten Kampar dalam Mengkampanyekan Wisata Ulu Kasok. Universitas Abdurrab. Pekanbaru.

Fitriani, R. (2019), Strategi Pengelolaan Akun Instagram Dalam Membangun Personal Branding Selebgram. Ilmu sosial dan ilmu politik. Universitas Sultan Ageng Tirtayasa.

Ghony, D., \& Almanshur, F. (2016). Metodologi Penelitian Kualitatif. Jogjakarta: Ar-ruzz Media.

Giantika, G,. (2019), Pemanfaatan Blog Pribadi di Instagram Sebagai Media Komunikasi Parenting (Studi Deskriptif Kualitatif Akun Instagram @annisast). Jurnal Komunikasi, 10(1), 1-9

Imanda, Yudha \& Zainal. (2015). Diakses pada tanggal 17 Agustus 2020, dari https://www.kompasiana.com/transakertapati/551adf65a333114721b65aa5/pengguna an-watermark-pada-foto-dalam-penerapan-fungsi-digital-right-management

Imawati, A., Solihah, A., Shihab, M. (2016). Analisi Personal Branding Fashion Blogger Diana Rikasari. Jurnal ilmu sosial dan ilmu politik. 5(3), 175-184

Lindawati, L. (2014). Media Lokal dan Suara Desa: Analisis Isi Surat Kabar Lokal Online di Kabupaten Banyumas. Jurnal komunikasi indonesia. 3(2). 109-118

Martono, N. (2014), Metode Penelitian Kuantitatif Analisis Isi dan Data Sekunder. Jakarta: PT RajaGrafindo Persada

Mee, G. (2018). Scrunch. Retrieved from What is a Good Engagement Rate on Instagram?: https://blog.scrunch.com/what-is -a-good-engagement-rate-on-instagram

Mulyana, A. (2010). Rahasia Menjadi Guru Hebat. Surabaya: Grasindo

Mustaqimmah, Nurul. (2017). Analisis Panik Moral pada Akun Instagram Awkarin. Seminar International Conference Universiti Kebangsaan Malaysia, Kuala Lumpur. 15 Oktober 2017

Priansa, D,. (2017), Komunikasi Pemasaran Terpadu. Bandung: CV Pustaka Setia 
Rampersad, Hubert K. (2008), Sukses Membangun Authentic Personal Branding, Edisi Indonesia, PPM, Jakarta.

Solis, Brian (2012) The Rise of Digital Influence. Diakses pada 15 Agustus 2019 dari https://techcrunch.com/2012/03/21/klout-kred-peerindex-radian6/

Somantri, R. (2005). Memahami Metode Kualitatif. Jurnal sosial humaniora. 9(2). 57-65

Soraya, I. (2017). Personal Branding Laudya Cynthia Bella Melalui Instagram (studi deskriptif kualitatif pada akun@Bandungmakuta).Jurnal komunikasi, VIII(2).31-37

Spesialisasi. (2019). Diakses pada 14 mei 2020, dari https://cerdasco.com/spesialisasi/

Surijah, A. (2017). Membedah Instagram: Analisis Isi Media Sosial Pariwisata Bali. Jurnal psikologi ilmiah. 9(1). 1-17

Tarigan, Z. (2018). Strategi Komunikasi Customer Care Officer PT.Honda Arista Ringroad Medan dalam Menangani Keluhan Pelanggan. Ilmu Sosial dan Ilmu Politik. Universitas Sumatra Utara. Sumatra Utara

Wahyunanda, K. (2019). Sebanyak Inikah Pengguna Instagram di Indonesia? Diakses pada tanggal $16 \quad$ Mei $2020, \quad$ dari https://www.gooogle.co.id/amp.kompas.com/tekno/read/2019/12/23/14020057/seban yak-inikah-jumlah-pengguna-Instagram-di-indonesia.

Yuli. (2011). Tentang Authenticity : Renungan di Hari Kartini. Diakses pada 14 mei 2020, 